\title{
The Relationship between Hidden Curriculum Perception and University Life Quality in Sports Education
}

\author{
Nurgül Özdemir \\ Department of Physical Education and Sports Education, \\ School of Physical Education and Sports Education, Adnan Menderes University, Aydın, Turkey
}

Copyright $\odot 2018$ by authors, all rights reserved. Authors agree that this article remains permanently open access under the terms of the Creative Commons Attribution License 4.0 International License

\begin{abstract}
The hidden programme defines the informal part of an educational programme, that's to say, the unwritten aspect the boundaries of which are not clearly define. The hidden programme is also the neglected part of the educational programme. The thing that determines the quality of university education is the academic and social life opportunities offered to students, as well as the social, economic and cultural qualities of the students. One of the important implications of the hidden programme can be observed on university life quality. It is aimed in this study to determine the views of the students on hidden curriculum and university life quality in sports education and to reveal whether there is a relationship between the students' hidden curriculum perceptions and university life quality they perceive. In order to determine hidden programme perceptions of the students, Hidden Programme Scale (r.88) developed by Arslan and Akbulut (4); so as to determine the university life quality levels, University Life Quality Scale (r.90)developed by Doğanay and Sarı (13) was used in the study. Besides, a personal information form developed by the researcher was also used in the research. The study group of the study was composed of 159 university students, 67 of whom were female and 92 of whom were male, studying at School of Physical Education and Sports. The data was analyzed using SPSS 21.00 statistical package programme. In the analysis of the data, descriptive statistics, independent group t-test, one-way ANOVA, simple correlation statistical techniques were used. As a result of the research, it can be said that hidden curriculum perceptions of the students can be regarded as moderate level (x: 3.15; I am neutral). It is seen that the mean score of hidden curriculum perception is the lowest at learning teaching process sub-dimension (x: 2.83; almost I am neutral). As another result of the research, it is seen that the university life quality level of the students was at moderate level (x: 3.15, I am neutral). In the research, it is seen that there is a
\end{abstract}

moderate level, positive, significant relationship between hidden curriculum perceptions of the students and their university life quality perceptions.

Keywords Hidden Programme, University Life Quality, Sports Education

\section{Introduction}

The main purpose of educational activities is to ensure that children and young people in the society are healthy, efficient, in harmony and of course beneficial for the society (43). According to Mandela (26), education has such a role in the society that promotes development and change, develops and transforms society. According to Mitra (27), education is the most significant element that the world's societies having desire to develop must handle. The provision of achieving the quality in education system passes through training qualified teachers for the system (22). One of the important tools for this is the quality of formal programme and hidden curriculum applied in teacher training institutions.

As education and instruction activities are purposeful and planned, these activities should be carried out in line with an education programmes. For this reason, all education and instruction institutions apply written education programmes formally prepared in advance. All the education and instruction activities in the institution are performed according to these programmes. However, students are influenced not only by this formal, planned and written programme but also by another programme that is not planned and written. Authors with this view point out that there are two types of programmes in each school (20). One of these programmes is the "formal programme", which is formal, written and clearly specified, and the other 
is the "hidden curriculum", which is informal, unclear and unspecified. These programmes are the road map of education.

Although the boundaries of formal programme are explicit and the scope of it is narrower, the boundaries of hidden curriculum are broader (6). In spite the fact that formal programme is well-known in education literature, hidden curriculum is not well-known enough. The concept of hidden curriculum, which was first used by Jackson in $1968(17,24,29,18)$ is better understood today and still attracts attention.

Jackson (19) defined hidden curriculum as a system of values that students are not fully aware of at the beginning of the school but that teachers, families, and administrators wish to reward their students intentionally.

Although hidden curriculum is not clearly defined, it includes undesired learning as well as the messages and behaviours that the students are expected to learn. Within this framework, it is also the point that the students perform the behaviours expected by their teachers as well as performing the behaviours expected by their peers. However, not all these behaviours may be desired behaviours. Therefore, some of these behaviours can be caused by undesired behaviours.

Although the curriculums formed by the combination of the curriculums of the courses taught at schools is the visible formal side of the education programme, the hidden curriculum constituting the hidden side of the education programme plays a crucial role both in acquiring the goals of the formal programme and in achieving their own goals.

No matter how good the formal programme is, the thoughts and behaviours of the administrators, teachers and students are more effective in the students' learning process (15).

As a matter of fact, the results of the researches conducted reveal that in the acquisition of values, for example, extra-curricular factors are the most, formal programme is the second most, and hidden curriculum is the third most effective (38).

Even if hidden curriculum is not clearly defined and intentionally managed as in the context of the formal programme, it aims at the behaviours that are intended to be systematically acquired by the students. However, it is quite difficult to achieve individual development for the members of the society under the formal programme framework in the realization process of these goals (10).

According to Tuncel (35), it is possible to express that while formal programmes developed by bureaucratic authorities are being developed, the scientific developments in that field are taken as basis besides the expectations of the social culture and society; in hidden curriculum shaped by the socio-cultural characteristics of the individuals, it is possible to find social rules and functioning without any changes. It can be said that while formal programmes developed mostly in a centralized understanding are being formed, philosophical, cultural and social dynamics of the society, its values, expectations and, of course, the scientific developments in the field are taken into consideration. Hidden curriculum that forms the hidden side of the education programme is shaped by the socio-cultural characteristics of the individuals and the institution.

According to another view, the reactions of the students who are exposed to the formal programme reveal the hidden curriculum. The impact of the students towards the hidden curriculum shapes the peer interaction, the class climate and, of course, the hidden curriculum from the beginning each time (23). Therefore, if the characteristics and functioning of an educational institution are being analyzed, it is also necessary to examine the hidden curriculum of that institution.

As in all educational institutions, two programmes, the formal and hidden, are effective in performing educational activities in higher education institutions. That is to say, universities also have a hidden curriculum (25). Although the curriculums of the same faculties and departments in different universities are largely alike, these programmes mostly differ from each other in university life quality created by their hidden curriculums. Hence, in all societies, the place of some universities in the society and the quality of the students they educate is regarded to be different and more significant when compared to others. If it was not so, the students of the same faculties and departments of different universities would graduate with the same qualifications. This can be regarded as the most important indicator of the fact that formal programme is not only effective itself at universities.

According to Eisner (14), the main reason for the difference between universities is the hidden curriculum. If formal programmes were only performed at schools, all the schools would have the same quality. Within this context, the difference in the hidden curriculum that such characteristics as the cultural characteristics, achievement levels, communication styles etc. of the students at school create is also the source of the difference among universities (14). The formal programmes prepared for universities usually include ideal views, thoughts, values and qualifications for that country and society. However, universities cannot achieve all the goals of this programme. Therefore, according to Ahola (1), the main source of the difference between the perfect university whose programme is identified with the formal programme and the actual university conditions is the hidden curriculum.

According to Jackson (19), hidden curriculum makes students acquire such behaviours as loyalty and obedience while making them individuals compatible with the society. Hidden curriculum is a tool that regulates the relationships in the class and shapes students according to the expectations of the community. However, the expectations and needs of the students are put on the back burner in this process. This is a factor that leads to a decrease in the school life quality of the students having education at that institution.

According to Tengilimoğlu (33), quality is the sum of 
the characteristics of a product or service based on its ability to meet the defined or possible needs.

Within the scope of life quality, physical functions of people, their psychological states, social relations within and out of the family, their interactions with the environment and their beliefs are included (5).

According to Sari (30), life quality expresses the general and consistent well-being, and the evaluation by the individual is usually focused on positive life experiences that create happiness, pleasure and satisfaction, and the contrary negative experiences.

School life quality will help the student exist as a happy individual in the school, feel himself as an individual belonging to that school during his/her time at school and in his/her free time, and speak highly of the school and this will have a positive impact on the student, and indirectly on the other students in the school and on the products of the education and instruction process (2).

University life quality expresses the appropriateness of the university life to the needs and expectations of the students, the satisfaction and pleasure with university life, that is to say, how the student defines and assesses his/her life conditions. While defining university life quality, the focus point is the positive life experiences that create happiness and the negative life experiences that create feelings of avoidance and discomfort.

According to Sirgy et al. (31), university life quality refers to the satisfaction that students experience during their university life.

According to Yüksel (40), one of the important reasons why the measures taken in order to reach the desired level of quality for higher education institutions did not achieve their aim is that the hidden curriculum is much more effective on the students than the formal programme.

The investigation of the students' satisfaction during their university life not only gives the administrators of the institutions and the academicians the opportunity to produce so that they could improve the university life quality but it can also lead to the necessary precautions about the negativities affecting the university life quality. It is not enough to focus only on the formal programme to achieve this and to educate qualified sports trainers. It is also necessary to focus on the hidden curriculum. In order to define the details of the hidden curriculum and to develop the programme it is required to make the necessary arrangements. For this reason, it is aimed in this study to determine the views of the students on hidden curriculum and university life quality in sports education and to reveal whether there is a relationship between the students' hidden curriculum perceptions and university life quality they perceive.

\section{Materials and Methods}

In this section, research model, the population and sample of the research, data collection tools, data collection process and statistical analysis process of the data are given.

\section{Research Model}

The research that is designed in the screening model, one of the quantitative research designs, is a study in the relational screening model aiming to explain the relationship between two or more variables (21). Screening surveys are the researches that aim to describe the qualities and views of large masses (7). In this study, the relationship between the perceived hidden curriculum and university life quality and the sub-dimensions was examined. In this respect, the study shows the characteristics of the relational screening model. In the research, it was also analyzed how the variables differed according to such variables as age, gender, specialty, smoking and alcohol use, social skills perception, and doing sports regularly.

\section{Study Group}

The sample of the study was composed according to the convenience sampling method, beginning from the most easily accessed participants. According to Büyüköztürk et al. (7), convenience sampling method is the sampling method by which the sample of the research is completed by beginning from the most easily accessed participants in order to reach the required number of participants in the study. The study group of the study was composed of 159 university students, 67 of whom were female and 92 of whom were male, studying at Adnan Menderes University School of Physical Education and Sports.

\section{Data Collection Tools}

As the data collection tool, Personal Information Form, Hidden Curriculum Scale (HCS) and University Life Quality Scale (ULCS), the details of which are given below were used in the study.

\section{(1) Personal Information Form}

In the study, personal information form developed by the researcher was used in order to determine the personal characteristics of the respondents.

\section{(2) Hidden Curriculum Scale}

The "Hidden Curriculum Scale" developed by Aslan and Akbulut (4) was used to determine the hidden curriculum perceptions of the students in the study. The scale consists of 21 items and three sub-dimensions explaining $50 \%$ of the variance. The sub-dimensions are defined as follows: Content (1-2-3-4-5-6-7-8-9-10-11-12), Learning and Teaching Process (13-14-15-16-17) and Assessment (18-19-20-21). The scale is a five-point Likert-type scale 
rated as "I totally disagree" (1 point), "I disagree" (2 points), "I am neutral" (3 points), "I agree" (4 points), and "I totally agree" (5 points). The Cronbach Alpha reliability coefficient of the scale was found as $\mathrm{r} .88$.

\section{(3) University Life Quality Scale}

The "University Life Quality Scale" (ÖYKÖ) developed by Doğanay and Sarı (13) was used to determine the university life quality levels of the students in the study. The scale consists of 33 items and seven sub-dimensions. The sub-dimensions are; Instructor-Student Communication (18-24-25-30-31-33); Identity (6-8-12-17-23); Social Opportunities (2-7-14-20-29); Participation in Decisions (4-11-16-22-27-32); Student-Student Communication (5-10-19-26); Future (1-13-28); and Classroom Environment (3-9-15-21), respectively.

The scale is a five-point Likert-type scale rated as "I totally disagree" (1 point), "I disagree" (2 points), "I am neutral" (3 points), "I agree" (4 points), and "I totally agree" (5 points). The Cronbach Alpha reliability coefficient of the scale was found as $\mathrm{r} .90$.

\section{Data Collection Process}

In the research process, all the data was collected by the questionnaires applied by the researchers to the students after getting the necessary permission from the instructors for the application before or after the class. All the applications were made with volunteer students in the standard class environment. In the applications, the questionnaires of the research were given to students. No identity information was requested from the participants; only the voluntary consent form was filled in. At the next stage, the completed questionnaires were exposed to preliminary examination, and the haphazardly filled questionnaires and those with various items or sections left empty were excluded from the evaluation and was not included in the analysis.

\section{Data Analysis}

The data of the study was analyzed using SPSS 21.00 statistical package program. In the analysis of the data; descriptive statistics, independent groups t-test, one way ANOVA, simple correlation statistical techniques were used.

\section{Findings}

It could be said as a result of the research that the perceptions of the students in terms of hidden curriculum of the School of Physical Education and Sports could be evaluated as high (x: 4.95) on the scale in general. The results related to this finding were given in Table 1.
Table 1. Hidden Curriculum Perception Levels of School of Physical Education and Sports Students

\begin{tabular}{|c|c|c|c|c|c|}
\hline Sub-dimensions & $\mathrm{n}$ & $\begin{array}{c}\text { Min. } \\
\text { Score }\end{array}$ & $\begin{array}{c}\text { Max. } \\
\text { Score }\end{array}$ & $\mathrm{x}$ & $\mathrm{sd}$ \\
\hline Content & 155 & 15 & 55 & 3.05 & 8.53 \\
\hline $\begin{array}{c}\text { Learning and } \\
\text { Teaching Process }\end{array}$ & 155 & 5 & 22 & 2.83 & 4.02 \\
\hline Assessment & 155 & 4 & 20 & 3.11 & 3.73 \\
\hline $\begin{array}{c}\text { The Scale in } \\
\text { General }\end{array}$ & 155 & 24 & 92 & 3.01 & 14.61 \\
\hline
\end{tabular}

$(\mathrm{p}<0,05)$

When Table 1 was examined, it was found that the mean score of hidden curriculum perceptions of the students was 3.05 in content sub-dimension, 2.83 in learning and teaching process sub-dimension, 3.11 in assessment sub-dimension, and 3.10 (I am neutral) in the scale in general. According to these results, it was seen that the lowest perceptions of the students in terms of hidden curriculum of the School of Physical Education and Sports were in learning and teaching process sub-dimension.

Descriptive statistics in terms of university life quality levels of the School of Physical Education and Sports students were given in Table 2 .

Table 2. University Life Quality Levels of School of Physical Education and Sports Students

\begin{tabular}{|c|c|c|c|c|c|}
\hline Sub-dimensions & $\mathrm{n}$ & $\begin{array}{c}\text { Min } \\
\text { Score }\end{array}$ & $\begin{array}{c}\text { Max } \\
\text { Score }\end{array}$ & $\mathrm{x}$ & $\mathrm{sd}$ \\
\hline $\begin{array}{c}\text { Instructor- } \\
\text { Student } \\
\text { Communication }\end{array}$ & 155 & 10 & 28 & 3.15 & 3.72 \\
\hline Identity & 155 & 5 & 24 & 3.03 & 3.70 \\
\hline $\begin{array}{c}\text { Social } \\
\text { Opportunities }\end{array}$ & 155 & 8 & 23 & 3.18 & 2.97 \\
\hline $\begin{array}{c}\text { Participation in the } \\
\text { Decisions }\end{array}$ & 155 & 9 & 28 & 3.07 & 3.53 \\
\hline $\begin{array}{c}\text { Student-Student } \\
\text { Communication }\end{array}$ & 155 & 7 & 18 & 3.29 & 2.35 \\
\hline $\begin{array}{c}\text { Future } \\
\text { Class Environment }\end{array}$ & 155 & 8 & 20 & 3.11 & 3.73 \\
\hline $\begin{array}{c}\text { The Scale in } \\
\text { General }\end{array}$ & 155 & 15 & 55 & 3.15 & 13.6 \\
\hline
\end{tabular}

$(\mathrm{p}<0,05)$

When Table 2 was analyzed, it was found that the mean score of the students' university life quality levels was 3.15 in the instructor-student communication sub-dimension, 3.03 in the identity sub-dimension, 3.18 in the social opportunities sub-dimension, 3.07 in the participation in the decisions sub-dimension, 3.29 in the student-student communication sub-dimension, 2.98 in the future sub-dimension, 3.11 in the class environment sub-dimension, 3.15 in the scale in general (I am neutral). According to these results, it was seen that the lowest perceptions of the students in terms of university life quality was in the future sub-dimension. Based on the fact that the mean score of the scale in general was 3.15, it could be said that university life quality that the students perceive in general was at moderate level (I am neutral). 
In the study, the correlation between hidden curriculum perceptions and university life quality levels of the students of the School of Physical Education and Sports was analyzed by correlation analysis and the results of the analysis were given in Table 3.

Table 3. The Results of Correlation Analysis between Hidden Curriculum Perceptions and University Life Quality Levels of the Students of the School of Physical Education and Sports

\begin{tabular}{|c|c|c|c|c|c|}
\hline $\begin{array}{l}\text { The Dimensions of } \\
\text { Hidden Curriculum } \\
\text { Dimensions } \\
\text { of University } \\
\text { Life Quality Scale }\end{array}$ & & Content & $\begin{array}{c}\text { Learning and } \\
\text { Teaching Process }\end{array}$ & Assessment & $\begin{array}{c}\text { Hidden Curriculum Scale } \\
\text { in General }\end{array}$ \\
\hline Instructor-Student Communication & $\begin{array}{l}\mathrm{r} \\
\mathrm{p}\end{array}$ & $\begin{array}{l}.03 \\
.74 \\
\end{array}$ & $\begin{array}{l}.16 \\
.09 \\
\end{array}$ & $\begin{array}{l}-.00 \\
.94 \\
\end{array}$ & $\begin{array}{l}.06 \\
.52 \\
\end{array}$ \\
\hline Identity & $\mathrm{r}$ & $\begin{array}{l}.51 \\
.00 \\
\end{array}$ & $\begin{array}{l}.61 \\
.00 \\
\end{array}$ & $\begin{array}{l}.47 \\
.00\end{array}$ & $\begin{array}{l}.59 \\
.00\end{array}$ \\
\hline Social Opportunities & $\begin{array}{l}\mathrm{r} \\
\mathrm{p}\end{array}$ & $\begin{array}{l}.34 \\
.00\end{array}$ & $\begin{array}{l}.32 \\
.00\end{array}$ & $\begin{array}{l}.28 \\
.00\end{array}$ & $\begin{array}{l}.36 \\
.00\end{array}$ \\
\hline Participation in the Decisions & $\mathrm{r}$ & $\begin{array}{l}.25 \\
.01 \\
\end{array}$ & $\begin{array}{l}.30 \\
.00\end{array}$ & $\begin{array}{l}.16 \\
.10 \\
\end{array}$ & $\begin{array}{l}.27 \\
.00\end{array}$ \\
\hline Student-Student Communication & $\begin{array}{l}\mathrm{r} \\
\mathrm{p}\end{array}$ & $\begin{array}{l}.31 \\
.00 \\
\end{array}$ & $\begin{array}{l}.39 \\
.00 \\
\end{array}$ & $\begin{array}{l}.24 \\
.01 \\
\end{array}$ & $\begin{array}{l}.35 \\
.00 \\
\end{array}$ \\
\hline Future & $\mathrm{r}$ & $\begin{array}{l}.11 \\
.26 \\
\end{array}$ & $\begin{array}{l}.11 \\
.27 \\
\end{array}$ & $\begin{array}{l}.03 \\
.74 \\
\end{array}$ & $\begin{array}{l}.10 \\
.30 \\
\end{array}$ \\
\hline Class Environment & $\begin{array}{l}\mathrm{r} \\
\mathrm{p}\end{array}$ & $\begin{array}{l}.41 \\
.00 \\
\end{array}$ & $\begin{array}{l}.37 \\
.00 \\
\end{array}$ & $\begin{array}{l}.20 \\
.03 \\
\end{array}$ & $\begin{array}{l}.39 \\
.00 \\
\end{array}$ \\
\hline University Life Quality Scale in General & $\begin{array}{l}\mathrm{r} \\
\mathrm{p}\end{array}$ & $\begin{array}{l}.43 \\
.00 \\
\end{array}$ & $\begin{array}{l}.51 \\
.00 \\
\end{array}$ & $\begin{array}{l}.31 \\
.00 \\
\end{array}$ & $\begin{array}{l}.47 \\
.00\end{array}$ \\
\hline
\end{tabular}

$(\mathrm{p}<0,05)$

When Table 3 was analyzed, it was found that there was a moderate level positive, significant relationship between the School of physical Education and Sports students' hidden curriculum perceptions in the content, learning and teaching process, and assessment sub-dimensions of the scale and university life quality perception scale in general, and identity sub-dimension of the scale; and a positive low level, significant relationship with social opportunities, participation in the decisions, communication with the students, and classroom environment sub-dimensions.

A moderate level, positive, significant relationship was found between the hidden curriculum scale in general and university life quality scale in general (r.47; p.00).

In the study, whether university life quality levels of the students of the School of Physical Education and Sports differed according to social skills variable was analyzed by ANOVA analysis, and the analysis results were given in Table 4.

When Table 4 was analyzed, it was seen that students' university life quality perceptions in instructor-student communication and future sub-dimensions of the scale differed significantly according to social skills variable. Therefore, it could be said that the students who define themselves more social when compared to others had higher scores of university life quality in both instructor-student communication and future sub-dimensions. In the research, it was also analyzed whether the students' hidden curriculum perception and university life quality scores differed according to such variables as age, gender, specialty, class, smoking and alcohol use, doing sports regularly but it was found that the difference was not significant. 
Table 4. ANOVA Analysis Results of the School of Physical Education and Sports Students' University Life Quality Levels According to Their Social Skills

\begin{tabular}{|c|c|c|c|c|c|c|}
\hline Sub-dimensions & Social Life & $\mathbf{n}$ & $\mathbf{x}$ & sd & f & $\mathbf{p}$ \\
\hline \multirow{3}{*}{$\begin{array}{l}\text { Instructor-Student } \\
\text { Communication }\end{array}$} & Participating in Social Activities & 108 & 19,2 & 3,71 & \multirow{3}{*}{3,0} & \multirow{3}{*}{, 05} \\
\hline & $\begin{array}{l}\text { Not Participating in Social Activities Except for Compulsory } \\
\text { Situations }\end{array}$ & 29 & 17,2 & 3,19 & & \\
\hline & $\begin{array}{l}\text { Not Participating in Social Activities Including Compulsory } \\
\text { Situations }\end{array}$ & 17 & 14,5 & 3,53 & & \\
\hline \multirow{3}{*}{ Identity } & Participating in Social Activities & 108 & 15,1 & 3,60 & \multirow{3}{*}{1,2} & \multirow{3}{*}{,29 } \\
\hline & Not Participating in Social Activities Except for Compulsory S. & 29 & 15,9 & 3,47 & & \\
\hline & Not Participating in Social Activities Including Compulsory S. & 17 & 11,5 & 9,19 & & \\
\hline \multirow{3}{*}{ Social Opportunities } & Participating in Social Activities & 108 & 16,1 & 2,83 & \multirow{3}{*}{1,9} & \multirow{3}{*}{, 14} \\
\hline & Not Participating in Social Activities Except for Compulsory S. & 29 & 14,8 & 3,66 & & \\
\hline & Not Participating in Social Activities Including Compulsory S. & 17 & 13,0 & 2,82 & & \\
\hline \multirow{3}{*}{ Participation in the Decisions } & Participating in Social Activities & 108 & 18,4 & 3,64 & \multirow{3}{*}{, 05} & \multirow{3}{*}{,94 } \\
\hline & Not Participating in Social Activities Except for Compulsory S. & 29 & 18,1 & 2,88 & & \\
\hline & Not Participating in Social Activities Including Compulsory S. & 17 & 18,0 & 4,24 & & \\
\hline \multirow{3}{*}{$\begin{array}{l}\text { Student-Student } \\
\text { Communication }\end{array}$} & Participating in Social Activities & 108 & 13,3 & 2,25 & \multirow{3}{*}{2,0} & \multirow{3}{*}{, 13} \\
\hline & Not Participating in Social Activities Except for Compulsory S. & 29 & 12,0 & 2,89 & & \\
\hline & $\begin{array}{l}\text { Not Participating in Social Activities Including Compulsory } \\
\text { Situations }\end{array}$ & 17 & 12,0 &, 00 & & \\
\hline \multirow{3}{*}{ Future } & Participating in Social Activities & 108 & 9,18 & 2,22 & \multirow{3}{*}{4,2} & \multirow{3}{*}{,01 } \\
\hline & Not Participating in Social Activities Except for Compulsory S. & 29 & 7,66 & 1,55 & & \\
\hline & Not Participating in Social Activities Including Compulsory S. & 17 & 6,00 & 4,24 & & \\
\hline \multirow{3}{*}{ Class Environment } & Participating in Social Activities & 108 & 13,4 & 2,41 & \multirow{3}{*}{, 15 } & \multirow{3}{*}{, 85} \\
\hline & Not Participating in Social Activities Except for Compulsory S. & 29 & 13,5 & 2,67 & & \\
\hline & Not Participating in Social Activities Including Compulsory S. & 17 & 12,5 & 2,12 & & \\
\hline \multirow{3}{*}{$\begin{array}{l}\text { University Life Quality Scale } \\
\text { in General }\end{array}$} & Participating in Social Activities & 108 & 104, & 13,4 & \multirow{3}{*}{2,4} & \multirow{3}{*}{09} \\
\hline & Not Participating in Social Activities Except for Compulsory S. & 29 & 99,3 & 13,2 & & \\
\hline & $\begin{array}{l}\text { Not Participating in Social Activities Including Compulsory } \\
\text { Situations }\end{array}$ & 17 & 87,5 & 10,6 & & \\
\hline
\end{tabular}

$(\mathrm{p}<0,05)$

\section{Conclusions}

In this research, it was aimed to determine hidden curriculum perception of the students in sports education and their university life quality perceived, and whether there was a relationship between hidden curriculum perception and university life quality.

As a result of the research, it can be said that hidden curriculum perceptions of the School of Physical Education and Sports students can be regarded as moderate level (x: 3.15; I am neutral). It is seen that the mean score of hidden curriculum perception is the lowest at learning teaching process sub-dimension (x: 2.83; almost I am neutral). Based on this result, it can be said that the students at the School of Physical Education and Sports find hidden curriculum moderately qualified. This can be explained in relation with the diversity of the components of hidden curriculum in the School of Physical Education and Sports. Competitions between classes, faculties and universities; courses like coaching and refereeing, which are of the activities that we can define within the content of hidden curriculum in the Schools of Physical Education and Sports, are widely available in the programme. Such activities not only play an important role in having knowledge about the profession but also are activities that willing participation is provided by the students. Therefore, hidden curriculum is perceived positively by the students. Besides, based on the fact that the conditions for the acceptance of students to the Schools of Physical Education and Sports (special talent examinations) depend on the interest and ability of the individual and thus, are different from other higher education programmes, it is expected that hidden curriculum perceptions of the students are more positive as a consequence of the fact that the students have chosen the school on purpose, far from being coincidence. However, the negativity of other elements of the content, learning and teaching process, and evaluation sub-dimensions of hidden curriculum may have negatively affected this expectation.

It is observed that the students' assessment of learning and teaching process sub-dimension of the scale is more negative when compared to the other sub-dimensions. The reason for this result, which is consistent with the findings 
of the researches by Türkoğlu (37), Erginer (16), and Deryakulu (11), can be explained by the fact that learning and teaching process lacks sufficient contemporary strategies, methods and techniques that activate the students in the lessons. Teaching the courses in such a way as to create a free learning environment that will lead the students to problem solving and not to inactivate them but to make them investigate can create an effect which may turn the students' negative perceptions into positive.

The universal ideal values are defined in the official program. But in reality, when looking at the programs in universities, it is seen that all applications are activities that position students as dependent and passive individuals (40). However, with programs designed in this way, it can be said that individuals cannot be made into a creative, individual who is free, scientific thinking, having a broad world view defined between the aims of higher education and society sensitive to human rights.

As Ahola (1) also points out, the way to solve the problems at higher education level is to design realistic, applicable programmes that are not left on paper and that are agreed by students, instructors and administrators. Besides, it can be said that communication and behavioural characteristics of the instructor in the learning and teaching process may have an impact on this result. The findings of the researches by Yüksel (41), Yücel and Kaynak (42) are also in line with this.

All the applications, activities, competitions, examinations, courses, seminars, student festivals, activities of student communities, conferences, student intercommunication, communication with the instructors, value system of the school, organizational scheme, administrative functioning, school culture etc. are hidden curriculum. The fact that a student successfully graduates from these departments, as in all higher education institutions, is not only linked to the success of the courses described in the formal programme but also to the fact that the student is well-conceived and can fulfil the requirements of hidden curriculum. Hence, according to Souriyavongsa et al. (32), university education should be able to question the previous learnings of the student.

It is not possible to educate qualified sports trainers by only developing and changing formal programmes. At the same time, it is necessary to determine the hidden curriculum and develop it in accordance with the aims of the institution and the society.

As a result of the research, it is seen that the university life quality level of the School of Physical Education and Sports students was at moderate level (x: 3.15, I am neutral). It is also observed that the lowest of the mean score of university life quality is in future sub-dimension of the scale (x: 2.98, I am neutral).

The reason for the moderate level of perceived university life quality of the students may be the fact that the university lacks sufficient opportunities for the students in spite of the fact that university life is a factor that enriches the life of the student. This situation may cause students to develop an unstable perception in terms of university life quality.

The fact that the school has the characteristics to ensure the student to develop attachment is related with the formation of the school culture, which allows hidden curriculum to be perceived positively. According to Çelik (9), all the individuals within the school are under the influence of this culture and because this interaction is reciprocal, organizational culture is created all over at any moment. According to Terzi (34), the individual sees it a privilege to belong to that culture and this can be explained as a factor that increases or decreases the university life quality. Hence, the findings of the researches by Özdemir (28), Yılmaz and Oğuz (39) also support this conclusion.

Although there is not a big difference between the sub-dimensions of university life quality scale in terms of the mean scores, it is seen that the mean score of the future sub-dimension is the lowest. This can be explained by the anxiety that students have about employment after graduation. In addition to this, the fact that the students perceive the examination they will have after graduation as an obstacle for themselves may be regarded as the reason of negative conclusions about the future. The employment ratio of sports trainers in today's conditions is another factor that contributes to this conclusion. The findings of the researches by Argon and Kösterelioğlu (3) also support this conclusion. However, in the studies by Doğanay and Sarı (13), the lowest university life quality mean score was detected in the classroom environment sub-dimension.

In the research, it is seen that there is a moderate level, positive, significant relationship between hidden curriculum perceptions of the students and their university life quality perceptions. According to this result, it can be said that as the perceptions of the students in terms of hidden curriculum increases, perceived university life quality increases, too. In the study by Argon and Kösterelioğlu (3), a moderate level positive, significant relationship was found between the school culture that we may consider as a sub-dimension of hidden curriculum and university life quality.

Since the borders of hidden curriculum are not clearly defined, a certain amount of effort and time is required for the students to discover the elements related with hidden curriculum and to fulfil the requirements. The fact that students can comprehend and fulfil the expected requirements means they comprehend hidden curriculum. However, this process is a painful process full of uncertainties for students. Therefore, the later the student's hidden curriculum perception matures, the more likely a negative hidden curriculum perception is to be developed, and thus, will lead to a decline in university life quality perceived by the student. In short, the positive linear relationship between hidden curriculum perception and university life quality revealed by the results of the research is a result that is expected. 
As a result of the research, it is found that university life quality perceived by the students differs according to their social skill levels. According to this result, the students who define themselves as more social when compared to others both in the instructor-student communication and in the future sub-dimensions of university life quality scale can be said to have higher scores of university life quality. In the researches by Cenkseven and Akbaş (8), Tuzgöl (36) and Doğan (12), it was found that the university students' well-being were significantly different on behalf of the outgoing individuals interacting with their environment.

In consequence, in order to educate qualified sports trainers, it is necessary to identify the components of hidden curriculum as well as formal programme and organize them better. Therefore, it will be easier for students to comprehend hidden curriculum. The faster the students cover a distance to understand hidden curriculum and fulfil the requirements, the higher the level of their university life quality will be. In this way, the students will be able to benefit more from the university process they are in and will have a better chance of getting prepared for their future lives. When considered from an institutional perspective, it will be possible to increase the quality of the education service by benefiting from the feedback in terms of the institution provided for the administrators and instructors through hidden curriculum.

\section{Suggestions}

The reasons for this conclusion can be examined in depth by future studies to be carried out in the qualitative research design. Therefore, it may be possible to develop hidden curriculum. In addition to this, it may be possible to analyze university life quality by the sports education hidden curriculum scale that can be developed specifically for sports education with a more specific perspective and to compare it with other scientific disciplines.

\section{REFERENCES}

[1] Ahola, S. (2000) Hidden Curriculum in Higher EducationSomething to Fear for or Comply to? Innovations in Higher Education Conference, Helsinki.

[2] Arıkan,G., Sarı,M. (2016) Lise Öğrencilerinde Okul Yaşam Kalitesinin İncelenmesi, International Journal of Contemporary Educational Studies (IntJCES), Haziran, 2(1), ISSN: 2548-9373

[3] Argon,T., Kösterelioğlu, M. (2009) Üniversite Öğrencilerinin Üniversite Yaşam Kalitesi Ve Fakülte Kültürüne İlişkin Algıları, Elektronik Sosyal Bilimler Dergisi, Güz, C.8,S. 30, ISSN: 1304-0278

[4] Aslan,S.,AkbulutN.(2016)Örtük Program Ölçeği: Ölçek Geliştirme Çalışması, Elektronik Sosyal Bilimler Dergisi,
Kış-, Cilt: 15, Sa1: 56, ISSN: 1304-0278

[5] Arslantaş D, Metintaş S, Unsal A, Kalyoncu C.( 2006) Eskişehir Mahmudiye İlçesi Yaşlılarında Yaşam Kalitesi. Osmangazi T1p Dergisi; 28: 81-9.

[6] Bolat,Y.(2014) Öğrenci Gözüyle Sınıfin Örtük Programı, Adıyaman Üniversitesi Sosyal Bilimler Enstitüsü Dergisi, ISSN: 1308-9196, Y11: 7 Say1: 18, Aralık

[7] Büyüköztürk, Ş., Akgün, E., Kılıç, Çakmak, E., Demirel, F. ve Karadeniz, Ş. (2012) Bilimsel Araştırma Yöntemleri, 11. Baskı, Ankara: Pegem A Yayınları

[8] Cenkseven,F.ve Akbaş,T.(2007)Üniversite Öğrencilerinde Öznel VePsikolojik İyi Olmanın Yordayıcılarının İncelenmesi.Türk Psikolojik Danışma ve Rehberlik Dergisi $3(27) 43,65$

[9] Çelik, V. (2007). Eğitimsel Liderlik. (4. Baskı). Ankara: Pegem A Yayınlar1.

[10] Çubukçu, Z. (2012). The Effect Of Hidden Curriculum On Character Education Process Of Primary School Students. Education Sci Theory Pract 12(2): Spring. (Supplementary special issue.)

[11] Deryakulu,,D.(1992) Öğretim Eleman1- Öğrenci Arası İletişimde İstenilen Öğretim Elemanı Davranışlarının Gösterilmesini Engelleyen Faktörler. (Yayınlanmamış Yüksek Lisans Tezi) Ankara: Ankara Üniversitesi.

[12] Doğan, T. (2006) Üniversite Öğrencilerinin İyilik Halinin İncelenmesi. Hacettepe Üniversitesi Eğitim Fakültesi Dergisi, 30, 120-129

[13] Doğanay, A. ve Sarı, M. (2006). Öğrencilerin Üniversitedeki Yaşam Kalitesine İliş̧in Algılarının Demokratik Yaşam Kültürü Cerçevesinde Değerlendirilmesi (Çukurova Üniversitesi örneği)" Türk Eğitim Bilimleri Dergisi. Bahar, Say1:2, Cilt: 4. İnternet adresi: http://www.tebd.gazi.edu.tr/arsiv/2006_cilt4/sayi2/107-128. pdf 12.03.2008

[14] Eisner, Elliot W. (1994). The Educational Imagination on the Design and Evaluation of Schools Programs. Third Edition. New York: Macmillan College Publishing Company.

[15] Ercan,İ,Yüksel,S.Özkya,G.Ocakoğlu,G.,Yüksel,A.,Uncu,Y. (2009) T1p Fakültesi Örtük Program Ölçeğinin Geliştirilmesi, Cerrahpaşa Tıp Dergisi, 40 (3): 81.87, ISSN 1300,5227

[16] Erginer, A. (1997) AİBÜ Eğitim Fakültesi Sınıf Öğretmenliği Bölümünde Öğretim Hizmeti Veren Öğretim Elemanlarının Yeterlilikleri. (Yayınlanmamış Yüksek Lisans Tezi) Bolu: Abant İzzet Baysal Üniversitesi.

[17] Gordon, D. (1982) "The Concept of The Hidden Curriculum" Journal of Philosophy of Education, 16, 187-198.

[18] Hemmings, A. (2000) "The Hidden Corridor Curriculum" High School Journal 83, 2,1-11.

[19] Jackson, P. W. (1968) Life in classrooms. New York: Holt, Rinehart and Winston Inc.Akt: Başar, M., Akan, M. Çankaya, İ. (2014) Örtük Program Çerçevesinde Okul Yöneticilerinin Yönetsel Uygulamalarının Değerlendirilmesi, Erzincan Üniversitesi Eğitim Fakültesi 
Dergisi Cilt-Sayı:16-1

[20] Jackson, P. W. (1992) "Conceptions of Curriculum and Curriculum Specialist" Handbook of Research on Curriculum. A Project of the American Educational Research Association. (Ed. P.W. Jackson) NewYork: Mac Millan Publishing Company.

[21] Karasar, N. (2009) Bilimsel Araştırma Yöntemleri, Ankara: Nobel Yayınları

[22] Keçici,S.E.,(2011) Almanya'da Öğretmen Eğitimi, M.Ü. Atatürk Eğitim Fakültesi Eğitim Bilimleri Dergisi Yıl: 2011, Sayı: 34, Sayfa: 117-132

[23] Kesici, E, T. ve Türkoğlu, A. (2012). “Ortaöğretim Kurumlarının Okul Yaşam Kalitesi Düzeyi ve Ortaöğretim Öğretmenlerinin Sınıf İçi İletişiminde Kullandıkları Örtük Program.” Pamukkale Üniversitesi Eğitim Fakültesi Dergisi, 31 (1). 147-160

[24] Lynch, K. (1989). The Hidden Curriculum. Reproduction in Education, A Reappraisal. London: The Falmer Press.

[25] Margolis, E., Romero, M. (1998) The Department İs Very Male, Very White Very Old And Very Conservative: The Functioning Of The Hidden Curriculum İn Graduate Sociology Departments. Harvard Educational Rewiew, 68 (1), 1-33.

[26] Mandela,N. (2014). Nelson Mandela Foundation, https://www.nelsonmandela.org/uploads/files/NMF_Annual _Report-2014 - WEB.pdf

[27] Mitra (2011). The Social and Economic Benefits of Public Education. Pennsylvania State University.

[28] Özdemir, A. (2006). Okul Kültürünün Oluşturulması Ve Çevreye Tanıtılmasında Okul Müdürlerinden Beklenen Ve Onlarda Gözlenen Davranışlar. Türk Eğitim Bilimleri Dergisi, 4(4). ss: 411-433 internet adresi: http://www.tebd.gazi.edu.tr/ arsiv/2006cilt4/sayi4/411-6.pdf

[29] Pinar, W.F.; Willam M.R.; Patrick Slattery; Peter M. Taubman (1995). Understanding Curriculum. New York: Peter Lang Publishing Inc.

[30] Sarı M. (2007) Demokratik Değerlerin Kazanımı Sürecinde Örtük Program: Düşük ve Yüksek “Okul Yaşam Kalitesi”ne Sahip İki İlköğretim Okulunda Nitel Bir Çalışma. Doktora Tezi, Çukurova Üniversitesi, Adana

[31] Sirgy, M. Joseph, Ed. (2007), From QOL Concepts to QOL Performance Measures: Proceedings of the 2007 ISQOLS Conference. Blacksburg, Virginia: International Society for Quality-of-Life Studies.
[32] Souriyavongsa, T. Abidin, M.J.Z. Rany S, Mei, L.L. and Aloysius, I.B. (2013) Investigating Learning English Strategies and English Needs of Undergraduate Students at the National University of Laos. English Language Teaching; Vol. $6(10)$.

[33] Tengilimoğlu D. (2011) Sağlık HizmetleriPazarlaması, Ankara, s. 308

[34] Terzi, A.R. (2007). Üniversite Öğrencilerinin Fakülte Kültürüne Yönelik Algıları (Giresun Eğitim Fakültesi örneği). Milli Eğitim Dergisi, 176, 98-108.

[35] Tuncel, İ. (2014) Eğitimde Program Geliştirme (ed. Hasan Şeker, Bölüm 2). Ankara: Anı Yayıncılık

[36] Tuzgöl Dost, M. (2006). Subjective Well-Being among University Students. Hacettepe Üniversitesi Eğitim Fakültesi Dergisi, 31, 188-197

[37] Türkoğlu, A. (1993). "Eğitim Yüksekokulu Program Uygulamalarında Karş1- laşılan Sorunlar" Eğitim Bilimleri 1. Ulusal Kongresi 24-28 Eylül 1990), Ankara: Ankara Üniversitesi Eğitim Bilimleri Fakültesi, Milli Eğitim Basımevi, s. 179- 189

[38] Yeşilyurt, E.,Kurt, İ. (2012). Değerleri Kazandırmasındaki Etkililik Açısından Resmi Ve Örtük Program İle Okul Dışı Etmenlerin Öğrenci Görüşleri Doğrultusunda Değerlendirilmesi. International Periodical for the Languages, Literature and History of Turkish or Turkic, 7(4):3253-3272.

[39] Y1lmaz, K. ve Oğuz, E. (2005). Eğitim Bilimleri Fakültesi Öğrencilerinin Fakülte Kültürüne İlişkin Algıları. Ankara Üniversitesi Eğitim Bilimleri Fakültesi Dergisi. 38 (1), 101122. Internet address: http://www.education. ankara.edu.tr/ ebfdergi/pdfler/2005_1/101-122.pdf

[40] Yüksel,S.,(2002) Yükseköğretimde Eğitim Öğretim Faaliyetleri ve Örtük Program, Uludağ Üniverstesi Eğitimi Fakültesi Dergisi, Cilt:XV, Say1. 1

[41] Yüksel, S. (2004) Örtük Program Eğitimde Saklı Uygulamalar. Ankara: Nobel Yayın Dağıtım.

[42] Yücel, C.;Kaynak, S. (2008) Öğretmenlerin Kişilik Özellikleri ve Örgütsel Vatandaşlık Davranışı, Selçuk Üniversitesi Sosyal Bilimler Dergisi, 20(1).

[43] Varış, F. (1998). Temel kavramlar ve program geliştirmeye sistematik yaklaşım. İçinde A.Hakan (Ed.), Eğitim bilimlerinde yenilikler (sf.3-19). Eskişehir: Anadolu Üniversitesi Açık Öretim Fakültesi Yayınları. 